\title{
Herbicides Persistence in Rice Paddy Water in Southern Brazil
}

\author{
Renato Zanella ${ }^{1}$, Martha B. Adaime ${ }^{1}$, Sandra C. Peixoto ${ }^{1}$,

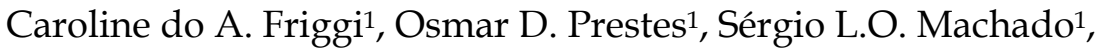 \\ Enio Marchesan ${ }^{1}$, Luis A. Avila ${ }^{2}$ and Ednei G. Primel ${ }^{3}$ \\ ${ }^{1}$ Federal University of Santa Maria, Santa Maria - RS, \\ ${ }^{2}$ Federal University of Pelotas, Pelotas - RS, \\ ${ }^{3}$ Federal University of Rio Grande, Rio Grande - RS, \\ Brazil
}

\section{Introduction}

Although the agricultural activity is only one of the several sources of water pollution, it is thought to be an important cause on reducing the water quality through pollution by agrochemicals, in special pesticides. Environmental water pollution by pesticides is a topic of current international concern with widespread ecological consequences. The selective use of pesticides to control pests (insects, weeds and diseases) and vectors of plant diseases can aims at the increase of production of food crops. In agricultural production, herbicides are often used to efficiently control of weeds, however there is widespread concern over the effects of these synthetic chemicals on native fauna and flora. The risks of herbicides use to kill or otherwise manage certain species of plants considered to be pests need to be balanced against the benefits to the production. Plant pests, or weeds, compete with desired crop plants for light, water, nutrients and space. To reduce the intensity of the negative effects of weeds on the productivity of desired agricultural crops, fields may be sprayed with an herbicide that is toxic to the weeds, but not to the crop species. Consequently, the pest plants are selectively eliminated, while maintaining the growth of the desired plant species.

The degradation of applied pesticides or their conversion into other products does not necessarily mean the loss of biological activity, and many times, this conversion can result in even more toxic products. The study of the persistence of pesticides in crop fields is of great importance in order to evaluate the risks of environmental pollution. Due to the model of agriculture adopted in Brazil, pesticide usage has become intensive and many related environmental problems are occurring (Steckert et al., 2009). The characteristics of rice fields, the climate conditions and the use of pesticides contribute to the enhanced risk of surface water pollution, justifying the need to quantify their degree of occurrence and to implement measures to prevent it.

The irrigated agriculture of the Rio Grande do Sul State, in the Southern Brazil, is responsible for more than $60 \%$ of the Brazilian rice production (CONAB, 2010), corresponding to more than one million hectares. The cultivation of irrigated rice can 
generates a great impact to the environment, so much in amount as in the quality of the surrounding water because demands intense agrochemical use, mainly herbicides, insecticides and fertilizers (Noldin et al., 2001).

In Brazilian conditions, the contribution of agriculture to water pollution is not well quantified, but in United States, 50 to $61 \%$ of the pollution load that affects lakes and rivers come from agriculture (Gburek \& Sharpley, 1997) being the superficial runoff the main mechanism of pesticides transport. Although agriculture is just one of the countless nonpoint-sources of pollution, it is generally targeted as the largest source among all pollutant categories. In Brazil, the culture of irrigated rice is notable in the Rio Grande do Sul State, with more than $70 \%$ of the Brazilian cultivated area of this culture, using circa of $5000 \mathrm{~m}^{3}$ of water per ha (Machado et al., 2006).

In most of the rice farms, the pesticide applications is followed by the irrigation and depending on the handling of the water and on the occurrence of rain after pesticide application, there is a risk that part of the applied compounds will be carried out of the area, contaminating water sources (Jury et al., 1990; Squillace \& Thurman, 1992; Solomon et al. 1996; Primel et al., 2005).

Irrigated farming for food production is the agricultural practice that most contributes to the deviation of water from its natural courses. Scarcity of water resources, which is occurring on a world-wide level, as well as the use of a large quantity of water, which is partially returned to its natural sources, makes irrigated rice farming a serious concern in terms of possible consequences for the environment, both in quantity and quality of the water sources (Kurz et al., 2009).

Rice productivity levels in Brazil are high, reaching an average value of approximately $6.0 \mathrm{t}$ ha $^{-1}$, similar to that obtained in countries with tradition in irrigated rice farming, such as the United States, Australia and Japan. However, this high productivity is associated with the intense use of pesticides (Baird \& Cann, 2005). Herbicides are potential contaminants of environmental water because they are directly applied to the soil or irrigating water. Thus, they can be leached to the surface water and transported into the groundwater (Hatrík \& Tekel, 1996; Zanella et al., 2002). According to specialized literature (Barceló \& Hennion, 1997; Primel et al.; 2005; Cabrera et al., 2008), a pesticide can pollute the aquatic environmental if its solubility in water is higher than $30 \mathrm{mg} \mathrm{L}^{-1}$; its $\mathrm{K}_{\mathrm{oc}}$, organic carbon partition coefficient, is less than 300-500; its $\mathrm{K}_{\mathrm{H}}$, Henry Law constant is less than $10^{-2} \mathrm{~Pa} \mathrm{~m}^{3}$ $\mathrm{mol}^{-1}$, its soil half-life is longer than 2-3 weeks and its water half-life is longer than 25 weeks.

In the pre-germinated system of irrigated rice cultivation frequently employed in Brazil, drainage from the area after sowing can set off serious environmental problems, as well as cause the loss of nutrients and/or pesticides that are in suspension in the irrigation water that is released. This has been evidenced in studies carried out by Primel (2003) and Machado (2003), where the occurrence of some herbicides, mainly those that present high persistence, was confirmed in river and irrigation waters. In Brazil some studies has been done until now to investigate the behavior and destination of herbicides in the systems related to the rice paddy fields in an attempt to evaluate the risk to the environment. (Zanella et al. 2002; Noldin et al., 1997: Bortoluzzi et al. 2006; Marchesan et al. 2007; Resgalla et al., 2007; Bortoluzzi et al. 2007; Grützmacher et al. 2008; Caldas et al. 2009; Silva et al., 2009; Caldas et al. 2010; Demoliner et al. 2010; Marchesan et al. 2010; Reimche, 2010). 
Herbicides can became a non-point source of pollution and, once in water, they spread in the environment, being hard to avoid their dispersal and their action on non-target organisms. Persistent and high-mobility herbicides have been detected in surface waters (Pereira \& Rostad, 1990; Thurman et al. 1991; Thurman et al. 1992; Huber et al. 2000) and underground (Walls et al., 1996; Kolpin et al., 1998), meaning risks for the environment, especially for the quality of water. In rice paddy fields, flooding increases the chance of herbicide transport through rain water or tailwater runoff, increasing the potential of environmental pollution. Due to cultural practices that include soil tillage, intensive use of irrigation by flooding, and high intensity of fertilizers and pesticides application, the rice paddy presents potential risk of decrease water quality. This problem can be even more intense in pre-germinated rice system where the initial drainage after soil preparation not only results in losses of considerable amounts of water but also carry sediments and, consequently, the loss of nutrients and pesticides adsorbed to the sediments or dissolved in the solution. Moreover, in most rice paddy, the applications of herbicides are followed by flooding and in some cases, the pesticides, especially some herbicides and insecticides, are applied directly in irrigation water. According to the water management adopted and to the rainfall after the application, there is a risk that the residues of these products are carried outside of the area and contaminating the water bodies, even though the concentration of herbicides in irrigation water is, in general, low (Squillace \& Thurmann, 1992; Sudo et al. 2002; Añasco et al., 2010).

Several surface water monitoring programs have been carried out to quantify the degree of water pollution by pesticides related to rice paddy fields (Kammerbauer \& Moncada, 1998; Huber et al., 2000; Kolpin et al., 2000; Bouman et al., 2002; Carabias-Martínez et al., 2002; Laganà et al., 2002; Cerejeira et al., 2003; Carabias-Martínez et al., 2003; Palma et al., 2004; Konstantinou et al., 2006; Marchesan et al., 2007; Siemering et al., 2008; Baugros et al., 2008; Woudneh et al., 2009; Añasco et al., 2010). Analysis of temporal variations of pesticides shows that herbicides present relatively higher concentrations in the earlier stages of the rice planting season, while insecticides and fungicides have relatively higher concentrations at the later stages (Añasco et al., 2010).

Rice crop conducted under flooded conditions is pointed out as being an activity of high pollution potential. The factors that contribute to this claim are the large amount of water used to maintain the flood, the usual proximity of the fields to surface water bodies, the predominant shallow aquifer in these areas, and the intentional and unintentional release of water from the field (Machado et al., 2006). Several studies investigated the extension of herbicides runoff from paddy fields to the environment. In general, high herbicide concentrations were usually observed in the stream water following pesticide application periods and are generally detected in concentrations in levels of ng L-1 for only 2 to 3 months after use. (Ueji \& Inao, 2001; Nakano et al., 2004; Numabe \& Nagahora, 2006; Son et al., 2006; Comoretto et al., 2008).

\section{Objective}

The aim of this chapter is to present results from the evaluation of the persistence of the currently used herbicides bentazon, bispyribac sodium, clomazone, imazapic, imazethapyr, metsulfuron-methyl, penoxsulam, propanil, quinclorac and 2,4-D in rice paddy water from fields located in the Rio Grande do Sul State, in Southern Brazil, in order to assess the 
pollution risk of water from surrounding areas. Field experiments were conducted in irrigated rice experiments carried out in the Weed Science Department of the Federal University of Santa Maria (UFSM). Analyses were performed in the Laboratory of Analysis of Pesticide Residues (LARP) from the Federal University of Santa Maria (UFSM). Water samples were collected periodically and the herbicide residues were preconcentrated by solid phase extraction (SPE) followed by the determination by Liquid Chromatography with Diode Array Detection (LC-DAD) or Liquid Chromatography coupled to tandem Mass Spectrometry (LC-MS/MS).

\section{Methods}

\subsection{Characterization of the physico-chemical properties of the herbicides}

The more important properties of the studied herbicides are described in this section. Table 1 presents information about the evaluated herbicides.

Bentazon, 3-(1-methylethyl)-(1H)-2,1,3-benzothiadiazin-4(3H)-one 2,2-dioxide, is a postemergence benzothiadiazinol herbicide used for selective control of broadleaf weeds and sedges in crops like rice, corn, beans and peanuts. Its selectivity is based on the ability of the crop plants to metabolize bentazon quickly to 6-OH- and 8-OH-bentazon and conjugate these with sugars, while weeds do not, so that photosynthesis is disrupted and the weeds die (Huber \& Otto, 1994). The small $\mathrm{K}_{\mathrm{ow}}$ value precludes bioaccumulation. Technical and formulated forms of bentazon are classified by EPA as practically nontoxic to fish. Bentazon does not bind to, or adsorb, to soil particles and it is highly soluble in water. These characteristics usually suggest a strong potential for groundwater contamination. Its rapid degradation is expected to prevent the contamination of groundwater. EPA estimates that bentazon may be found in about $0.1 \%$ of the rural drinking water wells nationwide. Bentazon has the potential to contaminate surface water because of both its mobility in runoff water and its pattern of use on rice. Bentazon appears to be stable to hydrolysis and has a half-life of less than $24 \mathrm{~h}$ in water because it undergoes photodegradation (EPA, 1985).

Bispyribac-sodium, sodium 2,6-bis(4,6-dimethoxypyrimidin-2-yloxy)benzoate, is a herbicide registered for use in irrigated rice farming in Brazil and in several other countries. It is indicated for the post-emergence control of grasses. This herbicide belongs to the toxicological class II, considered very toxic. The compound has a half-life in soil of less than 10 days (Ware, 1994; Vencill, 2002). Bispyribac-sodium presents a lethal dose of $3524 \mathrm{mg} \mathrm{kg}^{-1}$ when applied orally in rats, and presents $\mathrm{CL}_{50}$ for trout $(96 \mathrm{~h})>100 \mathrm{mg} \mathrm{L}^{-1}$ and $\mathrm{CL}_{50}$ for Daphnia $\left(48\right.$ h) > $100 \mathrm{mg} \mathrm{L}^{-1}$ (EPA, 2001; Tomlin, 2007).

By the Goss classification, considering the physicochemical properties, bispyribac sodium presented intermediate probabilities to be found in surface waters, showing Medium WaterPhase-Transport Runoff Potential (MWTRP) and Medium Sediment-Transport Runoff Potential (MSTRP) (Caldas et al., 2011).

Clomazone, 2-[(2-chlorophenyl)methyl]-4,4-dimethyl-3-isoxazolidinone, is moderately mobile in sandy soils and its half-life in soils range from 5 to 117 days, depending of the soil and climatic conditions (Curran et al., 1992; Kirksey et al., 1996; Mervosh et al., 1995). Studies show that the clomazone concentration in soil solution is dependent on the amount of carbon and water in the soil (Lee et al., 2004). The clomazone is widely used against 
species of annual broad leaf weeds and Grass in the cultivation of soybeans, cotton, rice, sugar cane, corn, tobacco and a variety of other vegetable crops (Zanella et al., 2000). It is stable at room temperatures for at least 2 years and it is also stable at $50{ }^{\circ} \mathrm{C}$ for at least 3 months. The properties of clomazone indicates its potential for aquatic environmental pollution and has been detected in the majority of the water samples collected from rivers located close to irrigated rice fields in the South of Brazil (Zanella et al., 2002).

Imazethapyr, 5-ethyl-2-[(RS)-4-isopropyl-4-methyl-5-oxo-2-imidazolin-2-yl]nicotinic acid, and imazapic, 2-[(RS)-4-isopropyl-4-methyl-5-oxo-2-imidazolin-2-yl]-5-methylnicotinic acid, are imidazolinones herbicides sold as a commercial mixture containing 75 and $25 \mathrm{~g}$ active ingredient $\mathrm{L}^{-1}$ of imazethapyr and imazapic, respectively. This product is applied in pre- and post-emergence for the control of red rice which cause damages in the production and commercialization of the grains (Kraemer, 2009).

The persistence of these herbicides in soil is influenced by the $\mathrm{pH}$ (Loux \& Reese, 1992), by the humidity (Baughman \& Shaw, 1996) and organic matter (Stougaard et al., 1990; Alister \& Kogan, 2005). The main dissipation mechanisms are the microbiological degradation (Goetz et al., 1990) and the photolytic decomposition (Mallipudi et al., 1991). Imazethapyr and imazapic undergoes limited biodegradation in anaerobic conditions (Senseman, 2007; Santos et al. 2008).

Metsulfuron-methyl, methyl 2-(4-methoxy-6-methyl-1,3,5-triazin-2-ylcarbamoylsulfamoyl) benzoate, is a residual sulfonylurea compound widely used as a selective pre- and postemergence herbicide due to its selectivity against a wide range of weeds in cereal, pasture, and plantation crops. It is a systemic compound with foliar and soil activity, and it works rapidly after it is taken up by the plant. Metsulfuron methyl is expected to have moderate to very high mobility and if released into water is expected to have little to no adsorption to suspended solids and sediment. Metsulfuron methyl is expected to biodegrade in water based on its behavior in soil.

Penoxsulam, 2-(2,2-difluoroethoxy)-N-(5,8-dimethoxy[1,2,4]triazolo[1,5-c]pyrimidin-2-yl)-6(trifluoromethyl)benzenesulfonamide, is a sulfonamide herbicide for post-emergence control of grasses, sedges and broadleaf weeds in paddy rice. Soil sorption values are inversely related with the $\mathrm{pH}$, indicating that penoxsulam is qualitatively mobile. EPA (2004) has classified this herbicide as a reduced risk pesticide but has also concluded that there are uncharacterized risks, particularly to plants and microbial communities.

Propanil, 3',4'-dichloropropionanilide, is one of the most used herbicides in the cultivation of irrigated rice in Brazil. It is a post-emergent selective herbicide of contact with short duration used to control the electron transport inhibition of photosynthesis in herbs of wide leaves (Tomlin, 2007). According to Barceló et al. (1998) it was also one of the most used in Tarragosa (Spain) and according to Coupe et al. (1998) it was extensively used in the area of the Mississipi Delta (USA). Various studies have pointed out that propanil is degraded quickly into 3,4-dichloroaniline (3,4-DCA) (Dahchour et al., 1986; Correa \& Steen, 1995; Barceló \& Hennion, 1997). Propanil is weakly adsorbed by the soil, is moderately mobile in sandy soils and of low mobility in clayey soils, with half-life of 1 to 3 days (Vencill, 2002).

Quinclorac, 3,7-dichloroquinoline-8-carboxylic acid, is widely used in post-emergence against species broad leaf weeds in the cultivation of irrigated rice. Quinclorac has variable 
mobility depending on soil type and organic matter and it can persist in the soil for one year affecting susceptible crops in rotation programs (Vencill, 2002). Quinclorac presented intermediate probabilities to be found in surface waters, showing Medium Water-PhaseTransport Runoff Potential (MWTRP) (Caldas et al., 2011).

2,4-D, (2,4-dichlorophenoxy)acetic acid, is a selective herbicide used to kill broadleaf weeds. 2,4-D is one of the most widely used herbicides in industrial, commercial, and government markets. Crops treated with 2,4-D include rice, corn, soybeans, wheat, sugarcane, and barley. Introduced in 1946, 2,4-D continues to be one of the most important herbicides across the globe. 2,4-D is readily broken down by microbes in soil and aquatic environments; halflife in soil is 7-10 days and the half-life in water is 3-28 days. There is little tendency of 2,4-D to bioconcentrate. Leaching to groundwater may occur in coarse and sandy soil that has a low organic content. Agricultural run-off containing 2,4-D may contaminate groundwater, which may impact drinking water in some areas (EPA, 2005). Because 2,4-D has demonstrated toxic effects on the thyroid and gonads following exposure, there is concern over potential endocrine-disrupting effects.

The herbicide 2,4-D has a low binding affinity in mineral soils and sediment, and in those conditions is considered intermediately to highly mobile. Although 2,4-D is highly mobile, rapid mineralization rates may reduce the potential of 2,4-D to affect groundwater (Boivin et al., 2005). The compound 2,4-D has been detected in streams and shallow groundwater at low concentrations, in both rural and urban areas (McPherson et al., 2003). In a monitoring study, traces of the herbicide 2,4-D were detected in $49.3 \%$ of finished drinking water samples and $53.7 \%$ of untreated water samples, with detections between 0.001 and $2.4 \mu \mathrm{g} \mathrm{L}^{-1}$ (USDA, 2007).

According to the GOSS criteria, regarding the water-phase-transport runoff potential, the herbicides imazethapyr and metsulfuron-methyl show high potential. Clomazone and imazapic besides presenting High Water-Phase-Transport Runoff Potential (HWTRP) showed Low Sediment-Transport Runoff Potential (LSTRP), which is a high indicative that these compounds have good chance to be found in surface waters. Some compounds such as penoxsulam show Low Water-Phase-Transport Runoff Potential (LWTRP) showing fewer tendencies to be found in surface waters. Bispyribac sodium and quinclorac due to their physicochemical properties, presented intermediate probabilities to be found in surface waters, in other words, Medium Water-Phase-Transport Runoff Potential (MWTRP) or associated with sediment (MSTRP). For the risk of contamination of the groundwater, according to the methods GUS and US-EPA, the herbicides bentazone, clomazone, imazethapyr, imazapic, metsulfuron-methyl, and quinclorac are classified as potential contaminants of groundwater. The herbicide bispyribac-sodium did not show any leaching tendency by both methods. Penoxsulam, propanil and 2,4-D show different classifications by the US-EPA and GUS methods, or due to the lack of physicochemical parameters the prediction was not possible. These differences between the methods can occur because they consider different physicochemical characteristics (Caldas et al., 2011).

The main physicochemical properties of the herbicides related to the persistence in water are: solubility in water, vapor pressure $(\mathrm{VP})$, octanol/water partition coefficient $\left(\mathrm{K}_{\mathrm{ow}}\right)$, acid dissociation constant $\left(\mathrm{pK}_{\mathrm{a}}\right)$, Henry's Law Constant $(\mathrm{H})$ and half-life $\left(\mathrm{t}_{1 / 2}\right)$. These properties can be used to estimate the risk of environmental pollution (Primel et al., 2005). According to Barceló \& Hennion (1997), acid pesticides presenting $\mathrm{pK}_{\mathrm{a}}<3-4$, basic pesticides: $\mathrm{pK}_{\mathrm{a}}>10$; 
polar have $\log \mathrm{K}_{\mathrm{ow}}<1-1.5$, non-polar: $\log \mathrm{K}_{\mathrm{ow}}>4-5$, and between these values the compounds are considered moderate polar. The pesticides with $\log \mathrm{K}_{\mathrm{ow}}>3.0$ undergoes bioaccumulation. The $\mathrm{K}_{\mathrm{oc}}$ is the soil organic carbon / water partition coefficient, which is the ratio of the mass of a chemical that is adsorbed in the soil per unit mass of organic carbon in the soil per the equilibrium chemical concentration in solution. $\mathrm{K}_{\mathrm{oc}}$ values depend on the hydrophobicity of the compounds and are useful in predicting the mobility of organic contaminants in soil. Higher $\mathrm{K}_{\mathrm{oc}}$ values correlate to less mobile organic compounds while lower $\mathrm{K}_{\mathrm{oc}}$ values correlate to more mobile organic contaminants.

\begin{tabular}{|c|c|c|c|c|c|c|c|}
\hline $\begin{array}{l}\text { Herbicides } \\
\text { (CAS number) }\end{array}$ & $\begin{array}{l}\text { Chemical } \\
\text { structure }\end{array}$ & $\begin{array}{l}\text { Solubility in } \\
\text { water, } \mathrm{mg} \mathrm{L}^{-1}\end{array}$ & \begin{tabular}{|c|}
$\mathrm{K}_{\mathrm{oc}}$ \\
$\mathrm{cm}^{3} \mathbf{g}^{-1}$
\end{tabular} & $\begin{array}{l}\text { Log } \\
K_{\text {ow }}\end{array}$ & $\mathrm{pK}_{\mathrm{a}}$ & $\begin{array}{c}\mathrm{VP}, \mathrm{mPa} \\
\left(20^{\circ} \mathrm{C}\right)\end{array}$ & $\begin{array}{c}\mathrm{KH}, \\
\mathrm{Pa} \\
\mathrm{m}^{3} \mathrm{~mol}^{-1}\end{array}$ \\
\hline $\begin{array}{l}\text { Bentazon } \\
(25057-89-0)\end{array}$ & & 570 & 34 & 5.8 & 3.2 & 0.17 & $7.4 \times 10^{-5}$ \\
\hline $\begin{array}{l}\text { Bispyribac } \\
\text { sodium } \\
\text { (125401-92-5) }\end{array}$ & & 73300 & 5000 & -1.03 & 3.35 & $5.5 \times 10^{-6}$ & $3.1 \times 10^{-11}$ \\
\hline $\begin{array}{l}\text { Clomazone } \\
(81777-89-1)\end{array}$ & & 1100 & $150-562$ & 2.54 & & 19.2 & $4.2 \times 10^{-3}$ \\
\hline $\begin{array}{l}\text { Imazapic } \\
(81334-60-3)\end{array}$ & & 2200 & 137 & 2.47 & $\begin{array}{l}2.0 \\
3.6\end{array}$ & $<0.013$ & n.a. \\
\hline $\begin{array}{l}\text { Imazethapyr } \\
(81335-77-5)\end{array}$ & & 1400 & 10 & 1.49 & $\begin{array}{l}2.1 \\
3.9\end{array}$ & $<0.013$ & $1.3 \times 10^{-2}$ \\
\hline $\begin{array}{l}\text { Metsulfuron- } \\
\text { methyl } \\
(74223-64-6)\end{array}$ & & 2790 & $2.9-27$ & -1.7 & 3.75 & $1.1 \times 10^{-7}$ & $4.5 \times 10^{-11}$ \\
\hline $\begin{array}{l}\text { Penoxsulam } \\
\text { (219714-96-2) }\end{array}$ & & 408 & 73.2 & -0.60 & 5.1 & $2.5 \times 10^{-11}$ & $2.9 \times 10^{-14}$ \\
\hline $\begin{array}{l}\text { Propanil } \\
(709-98-8)\end{array}$ & & 130 & $239-800$ & 3.3 & & 0.026 & $3.6 \times 10^{-3}$ \\
\hline $\begin{array}{l}\text { Quinclorac } \\
(84087-01-4)\end{array}$ & & 0.065 & 50 & -1.15 & 4.3 & $<0.01$ & $<3.7 \times 10^{-2}$ \\
\hline $\begin{array}{l}2,4-\mathrm{D} \\
(94-75-7)\end{array}$ & & 311 & 60 & $\begin{array}{l}2.6- \\
2.8\end{array}$ & 2.73 & 0.019 & $1.3 \times 10^{-5}$ \\
\hline
\end{tabular}

Table 1. Chemical structure and some physicochemical properties of the selected herbicides. $\mathrm{K}_{\mathrm{oc}}=$ soil/water partition coefficient; $\mathrm{K}_{\mathrm{ow}}=$ octanol/water partition coefficient, $\mathrm{pK}_{\mathrm{a}}=$ acid dissociation constant; $\mathrm{VP}=$ vapor pressure; $\mathrm{KH}=$ Henry's Law constant. (Barceló \& Hennion, 1997; Tomlin, 2007; Senseman, 2007; Dores \& De-Lamonica-Freire, 2001). 


\subsection{Field experiment}

The experimental fields used in the studies were from the Weed Science Department at the Campus of the Federal University of Santa Maria (UFSM), Rio Grande do Sul (Brazil), and the experiments were conducted in different rice planting season (1999 to 2010). Figure 1 present the where the experiments were conducted. The fields have a typical Albaqualfa soil, with medium texture, presenting the following characteristics: $44 \%$ sand, $32 \%$ silt, $23 \%$ clay and $1.8 \%$ organic material. Soil was prepared with disking and graded by water slide. A randomized complete block design with four replications was used, with plots of $4 \times 4 \mathrm{~m}$. The irrigation of each plot was done individually through a water-pump linked to a float hydrometer to keep a 10-cm deep water paddy. The treatments were with the application of the commercial formulated herbicides at recommended dose, in $\mathrm{g}$ active ingredient ha ${ }^{-1}$, how presented in Table 2. The herbicides were applied using $\mathrm{CO}_{2}$-pressurized backpack sprayers. Taking into account a $10-\mathrm{cm}$ water slide, the theoretical initial concentrations, in $\mu \mathrm{g} \mathrm{L}-1$, estimated for each herbicide is informed in Table 2.

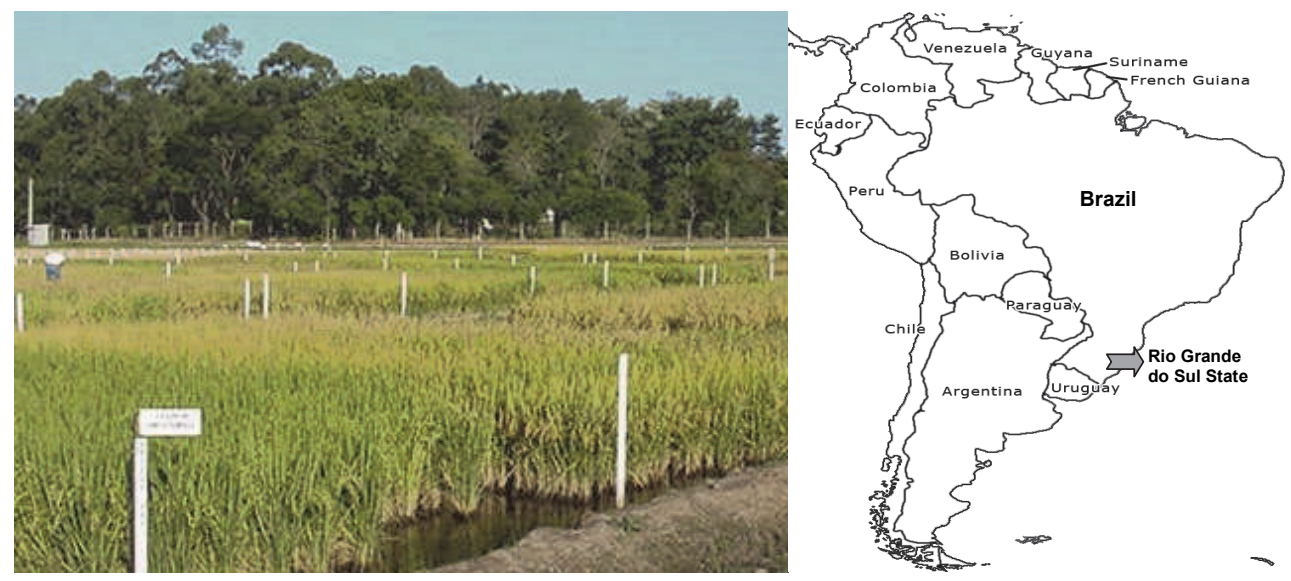

Fig. 1 . The rice paddy field where the experiments were conducted. Location: latitude $29^{\circ}$ $48^{\prime} 8.2^{\prime \prime}$ and longitude $53^{\circ} 43^{\prime} 22.6^{\prime \prime}$

\subsection{Determination of herbicide residues in water samples by Liquid Chromatography}

Analytical methods were developed and validated for the determination of the studied herbicide residues in paddy water using Liquid Chromatography with Diode Array Detection (LC-DAD) or Liquid Chromatography coupled with tandem Mass Spectrometry (LC-MS/MS). Samples were analyzed according the methods developed by Primel (2003), Zanella et al. (2003); Caldas et al. (2010) and Demoliner et al. (2010).

Aliquots of samples, previously filtered in membranes of $47 \mathrm{~mm}$ of diameter and $0.45 \mu \mathrm{m}$ of porosity were pre-concentrated in solid phase extraction (SPE) cartridges. The herbicides were eluted from the cartridges and the concentrations of the compounds were determined by LC-DAD or by LC-MS/MS with electrospray ionization (ESI). In order to achieve similar method limit of detection (LODm) values, the samples analyzed by LC-DAD were submitted to a higher preconcentration rate than the samples analyzed by LC-MS/MS. The LODm values for the selected herbicides are presented in Table 2. 
The parameters of validation of the method include analytical curve, linearity, limit of detection (LOD), limit of quantification (LOQ), precision, in terms of repetitivity and intermediate precision, and accuracy (recovery). Paddy water samples free of herbicides were used to assess the extraction efficiency of the proposed method and to observe the interfering peaks.

\subsubsection{Chemicals}

Herbicide standards were purchased from Dr. Ehrenstorfer GmbH (Augsburg, Germany). The stock solutions were prepared in methanol at a concentration of $1000 \mathrm{mg} \mathrm{L}^{-1}$ and kept at $-16{ }^{\circ} \mathrm{C}$. The analytical solutions were prepared by dilution of this stock solution in the mobile phase. Solvents were Nanograde ${ }^{\circledR}$ degree (Mallinckrodt, USA), water was purified in the system Direct-Q UV3® (resistivity $18.2 \mathrm{M} \Omega \mathrm{cm}$, Millipore, USA).

\subsubsection{Sampling}

Water samples were collected directly in $1 \mathrm{~L}$ amber glass bottles in each sampling site at different days after treatment (DAT). These bottles had been cleaned prior to sampling and was filled with the water sample to the top with as little remaining air as possible, and sealed tightly. All samples were properly labeled with details of the source and sampling date, and stored at $4{ }^{\circ} \mathrm{C}$ until the preconcentration step, which was carried out on the same day of the sampling.

\subsubsection{Liquid chromatography analyzes}

LC-DAD. Liquid chromatograph system from Varian (Palo Alto, USA) with a solvent delivery system model 9002, diode array detector (DAD) ProStar 335, system of data acquisition Star Workstation 6.0, analytical column Synergi $4 \mu$ Fusion RP-80 (250 x 4.6 mm i.d.; $4 \mu \mathrm{m}$ ) and guard-column of the same material $(4 \times 3 \mathrm{~mm})$, both from Phenomenex (Torrance, USA) was used.

LC-MS/MS. Analyses of the investigated herbicides were performed on a Waters Alliance 2695 Module HPLC, equipped with a quaternary pump, an automatic injector and a thermostatted column compartment, and detection on a Quattro micro API (triple quadrupole) mass spectrometer, equipped with an electrospray (ESI) ionization source (Waters, Milford, MA, USA). The chromatographic separation was performed with an XTerra ${ }^{\circledR}$ MS C18 $(3.0 \mathrm{~mm} \times 50 \mathrm{~mm}$ i.d., $3.5 \mu \mathrm{m})$ column Waters (Milford, MA, Ireland). Analytical instrument control, data acquisition and treatment were performed by the software MassLynx, version 4.1 (Micromass, Manchester, UK).

The main advantage of the LC-MS/MS method is the use of MS/MS detector because it provides a high sensitivity and permits the confirmation of the herbicides identity.

\subsubsection{Sample preparation}

The samples were acidified to $\mathrm{pH} 3.0$ with phosphoric acid prior the preconcentration step by SPE in cartridges containing octadecylsilane $\left(\mathrm{C}_{18}\right)$. The cartridges were conditioned with $3 \mathrm{~mL}$ of methanol, $3 \mathrm{~mL}$ of ultrapure water and $3 \mathrm{~mL}$ of ultrapure water acidified at $\mathrm{pH} 3.0$. After the conditioning step, water samples were percolated through the cartridges using a SPE manifold. 
For the LC-DAD analysis, samples were submitted to a high preconcentration rate to achieve the necessary method LOD. When LC-MS/MS was used, the sample preparation step was simplified using a low preconcentration rate, resulting in a faster method to perform. The use of LC-MS/MS allows the quantification with confirmation of the identity of herbicides.

\subsection{Determination of the half-life in paddy water}

The more stable the compounds, the longer it takes to break down. This can be measured in terms of its half life $\left(t_{1 / 2}\right)$, the time taken for the concentration of the compounds to be reduced to $50 \%$ of the initial value. The longer it takes to break down, the higher its persistence. The half life is unique to individual products but variable depending on specific environmental and application conditions.

Herbicides half-life values in water were calculated according to the following equation:

$$
\mathrm{t}_{1 / 2}=\ln 2 / \mathrm{k}=0.693 / \mathrm{k}
$$

where $t_{1 / 2}$ is the herbicide half-life in days, $\ln$ is the natural logarithm and $\mathrm{k}$ is the constant of the rate of the herbicides dissipation in water (Barceló \& Hennion, 1997). The calculation of the degradation constant $(\mathrm{k})$ was performed using the first-order rate equation:

$$
-\ln \left[\mathrm{C}_{\mathrm{t}}\right] /\left[\mathrm{C}_{\mathrm{o}}\right]=\mathrm{k} \cdot \mathrm{t}
$$

where $C_{t}$ represents the concentration at time $t ; C_{o}$ represents the initial concentration; and $k$ is the degradation constant, obtained by the inclination of the straight line.

\section{Results and discussion}

\subsection{Sample preparation and determination of herbicides residues in water samples}

The liquid chromatographic methods by LC-DAD and LC-MS/MS proved to be a good option for the determination of herbicide residues in paddy water, allowing the analysis with high selectivity and sensitivity. The method LOD values for herbicide residues in paddy water presented in Table 2, considering the pre-concentration step, were in the range of 0.05 to $0.2 \mu \mathrm{g} \mathrm{L}-1$. Good results for the preconcentration of herbicides from paddy water samples were obtained using C18 as sorbent with recoveries between 81 and 110\%, and RSD lower than $13.4 \%$.

Method LOD values were below the maximum levels permitted for pesticides in surface waters, which are of $1 \mu \mathrm{g} \mathrm{L}^{-1}$ for individual pesticides and of $5 \mu \mathrm{g} \mathrm{L}^{-1}$ for total pesticides in water that will be destined for human consumption after treatment (Kuster et al., 2006). The analytical methods were validated and demonstrated to be accurate and efficient for the quantification of the selected herbicides.

\subsection{Persistence and half-life of herbicides in rice paddy water}

Table 2 shows information about the analytical methods, recommended dose of the active ingredient applied in the rice fields, the theoretical initial concentration in irrigation water and the persistence and half-life $\left(t_{1 / 2}\right)$ of the herbicides in rice paddy water. 
The sampled paddy water presented in general $\mathrm{pH}$ values ranging from 5.5 to 6.5 and the air temperature during the experiments ranged from 9 to $38^{\circ} \mathrm{C}$.

\begin{tabular}{|c|c|c|c|c|c|c|c|}
\hline Herbicides & $\begin{array}{l}\text { LODm } \\
\left(\mu \mathrm{g} \mathrm{L}^{-1}\right)\end{array}$ & $\begin{array}{c}\text { Recovery } \\
(\%)\end{array}$ & $\begin{array}{l}\text { RSD } \\
(\%)\end{array}$ & $\begin{array}{l}\text { Recommended dose } \\
\left.\text { (g a.i. ha } \text { ha }^{-1}\right)^{a, c}\end{array}$ & $\begin{array}{c}\text { Detected } \\
\text { until (days) }\end{array}$ & $\begin{array}{c}\mathbf{t}_{1 / 2} \\
\text { (days) }\end{array}$ & References \\
\hline Bentazon & 0.1 & $89-107$ & $<7.5$ & $\begin{array}{l}960 \text { POST } \\
960 \text { POST }\end{array}$ & $\begin{array}{l}20 \\
22\end{array}$ & $\begin{array}{l}2.1 \\
3.8\end{array}$ & $\begin{array}{c}\text { Primel, } 2003 \\
\text { Machado, } 2003\end{array}$ \\
\hline $\begin{array}{l}\text { Bispyribac } \\
\text { sodium }\end{array}$ & 0.1 & $93-99$ & $<7.5$ & $\begin{array}{l}50 \text { POST } \\
50 \text { POST } \\
50 \text { POST }\end{array}$ & $\begin{array}{l}35 \\
21 \\
60 \\
\end{array}$ & $\begin{array}{c}2.4 \\
2.0 \\
12.4 \\
\end{array}$ & $\begin{array}{c}\text { Kurz et al., } 2007 \\
\text { Kurz et al., } 2009 \\
\text { Reimche, } 2010 \\
\end{array}$ \\
\hline Clomazone & 0.05 & $91-105$ & $<13.4$ & $\begin{array}{l}500 \text { POST } \\
500 \text { POST } \\
500 \text { POST } \\
500 \text { POST } \\
500 \text { POST } \\
500 \text { POST }\end{array}$ & $\begin{array}{l}24 \\
28 \\
35 \\
42^{\mathrm{b}} \\
31 \\
25 \\
\end{array}$ & $\begin{array}{c}3.5 \\
3.9 \\
2.1 \\
5 \mathrm{~b} \\
\\
\\
1.9\end{array}$ & $\begin{array}{c}\text { Primel, } 2003 \\
\text { Machado, } 2003 \\
\text { Gonçalves, } 2007 \\
\text { Santos, 2008 } \\
\text { Reimche, 2008 } \\
\text { Reimche, } 2010\end{array}$ \\
\hline Imazapic & 0.1 & $81-106$ & $<9.0$ & $\begin{array}{c}25 \text { PRE+25 POST } \\
25 \text { PRE } \\
25 \text { POST } \\
25 \text { POST } \\
\end{array}$ & $\begin{array}{l}24 \\
17 \\
14 \\
39 \\
\end{array}$ & $\begin{array}{c}16.1 \\
12.3 \\
3,9 \\
10.2 \\
\end{array}$ & $\begin{array}{c}\text { Gonçalves, } 2007 \\
\text { Gonçalves, } 2007 \\
\text { Gonçalves, } 2007 \\
\text { Reimche, } 2010 \\
\end{array}$ \\
\hline Imazethapyr & 0.1 & $89-107$ & $<7.1$ & $\begin{array}{c}75 \text { PRE+75 POST } \\
75 \text { PRE } \\
75 \text { POST } \\
75 \text { PRE } \\
75 \text { POST } \\
75 \text { POST } \\
\end{array}$ & $\begin{array}{l}28 \\
19 \\
14 \\
13 \\
20 \\
28 \\
\end{array}$ & $\begin{array}{l}7.1 \\
5.0 \\
3.1 \\
1,6 \\
5.2 \\
4.5 \\
\end{array}$ & $\begin{array}{c}\text { Gonçalves, } 2007 \\
\text { Gonçalves, } 2007 \\
\text { Gonçalves, } 2007 \\
\text { Santos, 2008 } \\
\text { Santos, 2008 } \\
\text { Reimche, 2010 } \\
\end{array}$ \\
\hline $\begin{array}{l}\text { Metsulfuron- } \\
\text { methyl }\end{array}$ & 0.1 & $87-106$ & $<11.7$ & 2 POST & 7 & 1.4 & Machado, 2003 \\
\hline Penoxsulam & 0.2 & $82-115$ & $<8.1$ & 48 POST & 60 & 12.4 & Reimche, 2010 \\
\hline Propanil & 0.05 & $92-98$ & $<13.1$ & $\begin{array}{l}3600 \text { POST } \\
3600 \text { POST } \\
3600 \text { POST }\end{array}$ & $\begin{array}{c}5 \\
8 \\
10\end{array}$ & $\begin{array}{l}0.8 \\
0.7 \\
0.5\end{array}$ & $\begin{array}{c}\text { Primel, } 2003 \\
\text { Machado, } 2003 \\
\text { Reimche, } 2008\end{array}$ \\
\hline Quinclorac & 0.2 & $89-110$ & $<5.1$ & $\begin{array}{l}375 \text { POST } \\
375 \text { POST } \\
375 \text { POST } \\
375 \text { POST }\end{array}$ & $\begin{array}{l}20 \\
21 \\
42 \\
84\end{array}$ & $\begin{array}{c}2.2 \\
3.7 \\
12.2 \\
15.5\end{array}$ & $\begin{array}{c}\text { Primel, } 2003 \\
\text { Machado, } 2003 \\
\text { Peixoto, } 2007 \\
\text { Reimche, } 2010 \\
\end{array}$ \\
\hline 2,4-D & 0.1 & $86-101$ & $<12.1$ & $\begin{array}{l}200 \text { POST } \\
200 \text { POST }\end{array}$ & $\begin{array}{l}12 \\
12\end{array}$ & $\begin{array}{l}1.4 \\
3.3\end{array}$ & $\begin{array}{c}\text { Primel, } 2003 \\
\text { Machado, } 2003\end{array}$ \\
\hline
\end{tabular}

Table 2. Figures of merit of the analytical methods, herbicide concentrations, persistence and half-life $\left(t_{1 / 2}\right)$ in rice paddy water. ${ }^{a}$ The values corresponding also the theoretical initial concentration, in $\mu \mathrm{g} \mathrm{L}^{-1}$, in irrigation water, calculated in $10 \mathrm{~cm}$ high water slide; bApplied dose: $1500 \mathrm{~g}$ a.i. ha-1; cPre- or Post-emergence application.

Considering the different field experiments conducted in several years at the same place we can point out that the results for each herbicide are similar, but different compounds present great difference related to the persistence and half-life in paddy water. The average persistence, in days, in decreasing order was quinclorac (48.7), bispyribac sodium (38.7), clomazone (30.8), imazapic (23.5), imazethapyr (20.3), bentazon (20.0), penoxsulam (12.4), 2,4-D (12.0) and propanil (7.5). The average half-life in paddy water in decreasing order was imazapic (10.6), quinclorac (10.0), bispyribac sodium (5.6), imazethapyr (4.4), clomazone (3.3), bentazon (2.1), 2,4-D (1.4), metsulfuron-methyl (1.4) and propanil (0.8). 
From the results presented it can be stated that rice paddy water need to be retained for different periods in the field after herbicide application depending of the herbicides used. The highest herbicides concentrations in water occur on the first days after the herbicide application decreasing with time, varying between the herbicides and years. The observance of the herbicides characteristics permit to reduce the water bodies pollution. Some herbicides were still detected after 30 days of the application. To minimize the risks of pollution of rivers and other water sources, it is important that the water containing pesticide residues remains in paddy for enough time to total herbicide dissipation.

In general, the herbicides concentrations found showed consistency with the ones reported in literature (Capri et al., 1999; Cumming et al., 2002; Quayle, 2003; Ross et al., 1989). So, the shorter the period between the herbicides application and the paddy water runoff, the higher the herbicides concentration in water and the potential risk to non-target organisms.

It is important to highlight that pesticide dissipation in irrigation water must be analyzed carefully because factors like soil preparation intensity, the period of time between the soil preparation and the rice broadcast, herbicide application time, water management, soil texture and soil chemical properties have a remarkable influence on herbicides persistence. The herbicides maintenance in rice paddy, through an irrigation management that reduces the water escape is important to avoid or to minimize herbicides pollution in water bodies.

For bentazon the results show that on average of three years, there was a decreasing of up to $64 \%$ of the herbicide concentration on the first seven days of the herbicide application. The average half-life of this herbicide was 2.1 days, with persistence of 20 days, being similar to the values reported by Crosby (1987), which mentioned that the concentration in paddy water fell to $22 \mu \mathrm{g} \mathrm{L}^{-1}$ in 6 days and was undetectable within 12 days.

In the conducted dissipation study, residues of bispyribac-sodium were found up to 60 days after application and the concentration at this time was of $0.3 \mu \mathrm{g} \mathrm{L}-1$. The average half-life of this herbicide was 5.6 days, with values between 2.0 and 12.4. These results corroborate Sanchez \& Tarazona (2006) who reported that the dissipation of bispyribac-sodium in soil is rapid, with half-life of 2 to 7.6 days, while the dissipation in water is highly variable, with half-life of 7.7 to 56 days. Bispyribac-sodium belongs to the toxicological class II, considered very toxic.

Clomazone is a quite persistent herbicide being detected in average up to 30 days, in concordance with the results obtained by Cumming et al. (2002). Clomazone was also the most frequently found herbicide in irrigation water in other studies (Quayle, 2003). The characteristic of this herbicide results in the maintenance of high concentration of clomazone in the rice field enhancing the possibility of environmental pollution. This is very important, since studies conducted with fishes had demonstrated short-term effects of exposure to environmentally relevant concentrations of clomazone on AChE activity in brain and muscle tissue (Crestani et al., 2007; Miron et al., 2005).

For the herbicide imazapic, the persistence in paddy water ranged from 14 to 39 days, with an average value of 23 days. The average half-life of this herbicide was 10.6, with values between 3.9 and 16.1 days. The higher values were observed when the herbicide was applied in pre- and also in post-emergence. 
Related to the herbicide imazethapyr, it presented a middle persistence in paddy water, with detectable residues from 13 to 28 days and an average persistence of 20.3 days. The half-life ranged from 1.6 to 7.1 , with average value of 4.4 days. The difference can be related to the application form of the commercial herbicide, which can be in pre- and postemergence, or only pre- or post-emergence. Similar results were reported by Marcolin et al. (2003), which found detectable concentrations of imazethapyr in water up to 30 days after application. Application in pre- and post-emergence had the highest half-life between the different application forms. For imazethapyr, photolysis is a major mechanism for its dissipation in anaerobic conditions, since the microbial degradation of the herbicide in these conditions is almost negligible (Senseman, 2007). Ávila (2005) also states that, when applied in pre-emergence, the herbicide has more time for sorption to the soil, reducing its availability in the soil solution. This can affect the photodecomposition of imazethapyr applied. Study presented by Santos et al. (2008) shows that imazethapyr half-life in paddy water varied between 1.6 days, for application at the recommended dose in pre-emergence, and 6.2 days, for application in post-emergence.

Silva et al. (2009) conducted a monitoring study in surface water of rice production areas in seven regions of southern Brazil associated with the rice cropping and stated that imazethapyr, carbofuran and fipronil were detected in all regions studied.

Martini et al. (2011) conducted a study about the imazethapyr + imazapic leaching in lowland soil related to different rice irrigation managements. The herbicides are persistent and mobile in soil, and thus, management practices can affect its dynamics. Soil samples were collected from a field experiment submitted to different rice irrigation managements. Samples were sliced at $5 \mathrm{~cm}$ intervals up to $30 \mathrm{~cm}$ in depth. The bioassay compared the growth of non-tolerant rice plants grown in soil subjected to the treatments. The herbicide is concentrated at 5-20 cm depth, 134 days after the product is applied in lowland soil.

Moraes et al. (2011) investigated the toxicological responses of Cyprinus carpio after exposure in paddy water containing imazethapyr and imazapic, applied at the recommended dose. After 30 days in rice field, brain AChE activity decreases and in muscle it was enhanced, pointing out short- and long-term effects of these herbicides on this fish.

The herbicide metsulfuron-methyl was persistent in paddy water for 7 days, with half-life of 1.4. The recommended dose $\left(2 \mathrm{~g}_{\text {i.a. }} \mathrm{ha}^{-1}\right)$ is very low resulting in an initial theoretical concentration of $2 \mu \mathrm{g} \mathrm{L}-1$. Pretto et al. (2011) studied the effects of commercial formulation containing metsulfuron-methyl on acetylcholinesterase (AChE), antioxidant profile and metabolic parameters in teleost fish (Leporinus obtusidens). This study pointed out long-term effects of exposure to commercial formulations containing metsulfuron-methyl on metabolic and enzymatic parameters.

Penoxsulam presented half-life of 12.4 days with relatively high remained concentration for several weeks. Detectable herbicide concentration was observed up to 60 days after the application of the recommended dose in post-emergence. The characteristic of this compound results in the maintenance of high concentration of penoxsulam in the rice field enhancing the possibility of environmental pollution.

The penoxsulam is rapidly adsorbed by the soil, except at $\mathrm{pH}$ above 8.0 (Senseman, 2007). In flooded soil, the penoxsulam occurs almost exclusively in the dissociated anionic form, but 
is somewhat persistent in water (Senseman, 2007). The dissipation of penoxsulam is rapid (Jabusch \& Tjeerdema, 2006) and occurs mainly by microbial degradation or photolysis (Senseman, 2007).

The herbicide propanil showed the shortest persistence, with detectable residues up to the tenth day after application and half-life of 0.8 days. The rapid reduction of the concentration of propanil from 3600 to $0.1 \mu \mathrm{g} \mathrm{\textrm {L } ^ { - 1 }}$ is due to its fast hydrolysis (Barceló et al., 1998). However, propanil and its metabolite 3,4-dichloroaniline (3,4-DCA) can constitute a risk for surface waters and for human health (Pereira \& Hostettler, 1992; Pastorelli et al. 1998). Monitoring studies of surface water carried out in the USA showed that 3\% of the 1560 analyzed samples contained propanil in a concentration of up to $2 \mu \mathrm{g} \mathrm{L}^{-1}$ and 3,4-DCA was detected in $50 \%$ of the samples with concentration of up to $8,9 \mu \mathrm{g} \mathrm{\textrm {L } ^ { - 1 }}$ (EPA, 2006). In our studies, the concentration of 3,4-DCA increases until the $2^{\text {nd }}$ day and then starts to decrease. The 3,4-DCA is detected up until the second week after the application of propanil and on the $14^{\text {th }}$ day after the application the presence of 3,4-DCA was still detected at a concentration of $1.6 \mu \mathrm{g} \mathrm{L} \mathrm{L}^{-1}$. Studies on the persistence of propanil in irrigated rice conditions conducted by Deul et al. (1977) showed that its dissipation occurs within 24 hours and that the amount of dissipated propanil corresponds to the concentration of 3,4-dichloroaniline (DCA), indicating biological degradation of propanil to DCA.

Quinclorac presented average half-life of 10 days with relatively high remained concentration until the seventh day (232 $\mu \mathrm{g} \mathrm{L}-1$, average) representing $39 \%$ of the applied concentration. Detectable herbicide concentrations were observed in average up to 48 days after the application. Crosby (1987) published that in USA, under field conditions, quinclorac dissipated to undetectable levels in 31 days. Vencill (2002) reported that quinclorac present variable mobility depending on soil type and organic matter and it can persist in the soil for one year affecting susceptible crops in rotation programs.

For the herbicide 2,4-D, the persistence in paddy water was 12 days, varying the concentration from 2 to $50 \mu \mathrm{g} \mathrm{L}^{-1}$ at the end of the first week. The average half-life of this herbicide was 1.4 days. In water, the speed of 2,4-D degradation is fast depending on: concentration of nutrients, sediments, dissolved organic carbon and water oxygenation (Sanches-Brunete et al., 1991). Under simulated conditions, studies showed that light is also an important element on 2,4-D degradation, showing that this herbicide under light degradated faster than quinclorac (Lavy et al., 1998).

\section{Conclusions}

The information obtained with the field experiments allows a better understanding of the behavior of the herbicides in rice paddy water. The sample preparation by SPE followed by the analysis by LC-DAD or LC-MS/MS has proven to be efficient to show the decrease of the herbicides concentrations after the application of the commercial formulations at the field. LC-MS/MS permits a better quantification with confirmation of the compounds. The developed methods presented method limit of detection between 0.05 and $0.2 \mu \mathrm{g} \mathrm{L}^{-1}$ permitting adequate analyses of the paddy water samples from the diverse field experiments conducted in a period of several years. No interferences from the matrix was observed during the quantification of the herbicide residues. 
Analyzing the results obtained, it can be recommended that irrigation water should be maintained, after application of the selected herbicides, for at least 20 days for the most herbicides and more than 30 days when more persistent herbicides, like quinclorac, bispiribac-sodium, clomazone and penoxsulam are used. This time, before releasing the water into the environment, is very important to reduce the pollution of water courses with herbicide residues. From the experiments repetitions it can be also concluded that the climatic conditions are very important in the process of decrease of the concentration in rice paddy water. Also the storage of rainwater, through irrigation managements, is very important to reduce the runoff of water from the paddy fields and the mass of pesticide transported to the environment.

\section{Acknowledgments}

Authors are grateful to the financial support and fellowships from $\mathrm{CNPq}$ (Brazil) through the projects MCT/CNPq/CT-HIDRO 01-2003 Process 503604/2003-8, MCT/CNPq/CTHIDRO/SEAP 035-2007 Process 552546/2007-0 and MCT/CNPq 15-2007 Process 482578/ 2007-6. The authors thank all the collaborators involved with the conduction of the studies.

\section{References}

Alister, C. \& Kogan, M. (2005). Efficacy of imidazolinone herbicides applied to imidazolinone-resistant maize and their carryover effect on rotational crops. Crop Protection, Vol. 24, No. 4, 375-379. ISSN 02612194.

Añasco, N.C.; Koyama, J. \& Uno, S. (2010). Pesticide residues in coastal waters affected by rice paddy effluents temporarily stored in a wastewater reservoir in southern Japan. Archives of Environmental Contamination and Toxicology, Vol. 58, No. 2, 352360, ISSN 1432-0800.

Añasco, N.C.; Uno, S.; Koyama, J.; Matsuoka, T. \& Kuwahara, N. (2010). Assessment of pesticide residues in freshwater areas affected by rice paddy effluents in Southern Japan. Environmental Monitoring and Assessment, Vol. 160, No. 1-4, 371-83, ISSN 1573-2959.

Avila, L.A. de (2005). Imazethapyr: red rice control and resistance, and environmental fate. Doctoral dissertation, Texas A\&M University, Stanford-USA. $81 \mathrm{p}$.

Baird, C. \& Cann, M. (2005). Environmental Chemistry, 3rd ed., W. H. Freeman, ISBN 0716748770, New York.

Barceló, D. \& Hennion, M.C. (1997). Trace Determination of Pesticides and their Degradation Products. Elsevier Science B.V, ISBN 9780444818423, Amsterdam.

Baughman, T.A. \& Shaw, D.R. (1996). Effect of wetting/drying cycles on dissipation of bioavailable imazaquin. Weed Science, Vol. 44, No. 2, 380-382. ISSN 1550-2759.

Baugros, J.B.; Giroud, B.; Dessalces, G.; Grenier-Loustalot, M. \& Cren-Olivé, C. (2008). Multiresidue analytical methods for the ultra-trace quantification of 33 priority substances present in the list of REACH in real water samples, Analityca Chimica Acta, Vol. 607, No. 28, 191-203, ISSN 0003-2670.

Bortoluzzi, E.; Rheinheimer, D.; Gonçalves, C.; Pellegrini, J.; Zanella, R. \& Copetti, A. (2006). Contaminação de águas superficiais por agrotóxicos em função do uso do solo numa microbacia hidrográfica de Agudo, RS, Revista Brasileira de Engenharia Agrícola e Ambiental, Vol. 10, No. 4, 881-887, ISSN 1807-1929. 
Bortoluzzi, E.; Rheinheimer, D.; Gonçalves, C.; Pellegrini, J.; Maroneze, A.; Kurz, M.; Bacar, N. \& Zanella, R. (2007). Investigation of the occurrence of pesticide residues in rural wells and surface water following application to tobacco, Química Nova, Vol. 30, No. 8, 1872-1876, ISSN 0100-4042.

Bouman, B.A.M.; Castañeda, A.R.; Bhuiyan, S.I. (2002). Nitrate and pesticide contamination of groundwater under rice-based cropping systems: past and current evidence from the Philippines. Agriculture Ecosystem E Environment, Vol. 92, No. 2-3, 185-199, ISSN 0167-8809.

Boivin, A.; Amellal, S.; Schiavon, M. \& van Genuchten, M.T. (2005). 2,4dichlorophenoxyacetic acid (2,4-D) sorption an degradation dynamics in three agricultural soils. Environmental Pollution, Vol. 138, No. 1, 92-99, ISSN 0269-7491.

Cabrera, L.; Costa, F. \& Primel, E. (2008). Estimativa de risco de contaminação das águas por pesticidas na região sul do estado do RS, Química Nova, Vol. 31, No. 8, 1982-1986, ISSN 0100-4042.

Caldas, S.; Demoliner, A. \& Primel, E. (2009). Validation of a Method using Solid Phase Extraction and Liquid Chromatography for the Determination of Pesticide Residues in Groundwaters, Journal of the Brazilian Chemical Society, Vol. 20, No. 1, 125-132, ISSN 0103-5053.

Caldas, S.; Demoliner, A.; Costa, F.; D’Oca, M. \& Primel, E. (2010) Pesticide Residue Determination in Groundwater using Solid-Phase Extraction and HighPerformance Liquid Chromatography with Diode Array Detector and Liquid Chromatography-Tandem Mass Spectrometry, Journal of the Brazilian Chemical Society, Vol. 21, No. 4, 642-650, ISSN 0103-5053.

Caldas, S.S.; Zanella, R. \& Primel, E.G. (2011). Risk Estimate of Water Contamination and Occurrence of Pesticides in the South of Brazil, In: Herbicides and Environment, Andreas Kortekamp, (Ed.), 471-492, InTech, ISBN 978-953-307-476-4, Rijeka, Croatia.

Capri, E.; Cavanna, S.; Trevisan, M. (1999). Ground and surface water bodies contamination by pesticides use in paddy field. In: Environmental risk parameters for use of plant protection products in rice, Capri E. et al. (Ed.), 48-71, Tipolitografia, Piacenza.

Carabias-Martínez, R.; Rodríguez-Gonzalo, E.; Herrero-Hernández, E.; Román, F. \& Flores, M. (2002). Determination of herbicides and metabolites by solid-phase extraction and liquid chromatography Evaluation of pollution due to herbicides in surface and groundwaters, Journal of Chromatography A, Vol. 950, No. 1-2, 157-166, ISSN 0021-9673.

Carabias-Martínez, R.; Rodríguez-Gonzalo, E.; Fernández-Laespada, M.E.; Calvo-Seronero, L. \& Sánchez-San Román, F.J. (2003). Evolution over time of the agricultural pollution of waters in an area of Salamanca and Zamora (Spain). Water Research, Vol. 37, No. 4, 928-938, ISSN 0043-1354.

Cerejeira, M.; Viana, P.; Batista, S.; Pereira, T.; Silva, E.; Valério, M.; Silva, A.; Ferreira, M. \& Silva-Fernandes, A. (2003). Pesticides in Portuguese surface and ground Waters, Water Research, Vol. 37, No. 5, 1055-1063, ISSN 0043-1354.

Comoretto, L.; Arfib, B.; Talva, R.; Chauvelon, P.; Pichaud, M.; Chiron, S. \& Höhener, P. (2008). Runoff of pesticides from rice fields in the Ile de Camargue (Rhône river delta, France): Field study and modeling. Environmental Pollution, Vol. 151, No. 3, 486-493, ISSN 02697491.

CONAB (2010). Séries históricas: grãos. August 2010. Available from: http:/ / www.conab.gov.br/conteudos.php?a=1252\&t=2. 
Correa, I.E. \& Steen, W.C. (1995). Degradation of propanil by bacterial isolates and mixed populations from a pristine lake. Chemosphere, Vol. 30, No. 1, 103-116, ISSN 00456535.

Coupe, R.H.; Thurman, E.M. \& Zimmerman, R. (1998). Relation of usage to occurrence of cotton and rice herbicides in three streams of the Mississippi Delta. Environmental Science and Technology, Vol. 32, No. 23, 3673-3680. ISSN 1520-5851.

Crestani, M.; Menezes, C.; Glusczak, L.; Miron D.S.; Spanevello, R.; Silveira, A.; Gonçalves, F.F.; Zanella, R.; Loro, V.L. (2007). Effect of clomazone herbicide on biochemical and histological aspects of silver catfish (Rhamdia quelen) and recovery pattern. Chemosphere, Vol. 67, No. 11, 2305-2311, ISSN 0045-6535.

Crosby, D.R. (1987). Environmental fate of pesticides-87. California Rice Research Board. Available from: http:/ / www.syix.com/rrb/87rpt/Enviro.htm.

Cumming, J.P.; Doyle, R.B. \& Brown, P.H. (2002). Clomazone dissipation in four Tasmanian topsoils. Weed Science, Vol. 50, No. 3, 405-409. ISSN 1550-2759.

Curran, W.S.; Liebl, R.A. \& Simmons, F.W. (1992). Effects of tillage and application methods on clomazone, imazaquin, and imazethapyr persistence. Weed Science, Vol. 40, No. 3, 482-489, ISSN 1550-2759.

Dahchour, A.; Bitton, G.; Coste, C.M. \& Bastide, J. (1986). Degradation of the herbicide propanil in distilled water. Bulletin of Environmental Contamination and Toxicology, Vol. 36, No. 4, 556-562, ISSN 1432-0800.

Demoliner, A.; Caldas, S.; Costa, F.; Gonçalves, F.F.; Clementin, R.; Milani, M. \& Primel, E.G. (2010). Development and Validation of a Method Using SPE and LC-ESI-MS-MS for the Determination of Multiple Classes of Pesticides and Metabolites in Water. Journal of the Brazilian Chemical Society, Vol. 21, No. 8, 1-10, ISSN 0103-5053.

Deul, L.E.; Brown, K.W.; Turner, F.C.; Westfall, D.G. \& Price, J.D. (1977). Persistence of propanil, DCA, and TCAB in soil and water under flooded rice culture. Journal of Environmental Quality, Vol. 6, No. 2, 127-132, ISSN 1537-2537.

Dores, E.F.G.C. \& De-Lamonica-Freire, E.M. (2001). Aquatic environment contamination by pesticides. Case study: water used for human consumption in Primavera do Leste, Mato Grosso. Química Nova, Vol. 24, No. 1, 27-36. ISSN 0100-4042.

Environmental Protection Agency - EPA (1985). Chemical fact sheet for bentazon and sodium bentazon. Fact sheet no. 64. Office of Pesticide Programs. Washington, DC.

Environmental Protection Agency - EPA (2001). Bispyribac-Sodium: Pesticide Tolerance Related Material, Vol. 66, No. 181. Available from: http://www.gpo.gov/fdsys/pkg/FR-2001-09-18/html/01-23227.htm.

Environmental Protection Agency - EPA (2004). Pesticide Fact Sheet No.185; U.S. EPA Office of Prevention, Pesticides and Toxic Substances: Washington, DC.

Environmental Protection Agency - EPA (2006). Overview of propanil risk assessment. Available from: http:/ / www.epa.gov/pesticides/reregistration/status.htm.

Gburek, W.J. \& Sharpley, A.N. (1997). Hydrologic controls on phosphorus loss from upland agricultural watersheds. Journal of Environmental Quality, Vol. 27, No. 2, 267-277, ISSN 1537-2537.

Goetz, A.; Lavy, T. \& Gbur, E. (1990). Degradation and Field persistence of imazethapyr. Weed Science, Vol. 38, No. 2, 421-428, ISSN 1550-2759.

Gonçalves, F.F. (2007). Study of methods using HPLC-DAD and LC-MS/MS for the determination of herbicide residues in water and soil of the irrigated rice cultivation. Doctoral thesis, Universidade Federal de Santa Maria, Brazil. 
Grützmacher, D.; Grützmacher, A.; Agostinetto, D.; Loeck, A.; Roman, R.; Peixoto, S. \& Zanella, R. (2008). Monitoramento de agrotóxicos em dois mananciais hídricos no sul do Brasil, Revista Brasileira de Engenharia Agrícola e Ambiental, Vol. 12, No. 6, 632637, 1807-1929. ISSN 1807-1929.

Hatrík, S. \& Tekel, J. (1996). Extraction methodology and chromatography for the determination of residual pesticides in water. Journal of Chromatography A, Vol. 733, No. 1-2, 217-233, ISSN 0021-9673.

Huber, R. \& Otto, S. (1994). Environmental behavior of bentazon herbicide. Reviews of Environmental Contamination and Toxicology, Vol. 137, No. 1, 111-134, ISSN 01795953.

Huber, A.; Bach, M. \& Frede, H.G. (2000). Pollution of surface waters with pesticides in Germany: modeling non-point source inputs. Agriculture Ecosystem and Environment, Vol. 80, 191-204, ISSN 0167-8809.

Jabusch, T.W. \& Tjeerdema, R.S. (2006). Photodegradation of penoxsulam. Journal of Agricultural and Food Chemistry, Vol. 54, No. 16, 5958-5961, ISSN 1520-5118.

Jury, W. A., Russo, D., Streile, G. \& Abd, H.E. (1990). Evaluation of volatilization by organic chemicals residing below the soil surface. Water Resources Research, Vol. 26, No. 1, 13-20, ISSN 0043-1397.

Kammerbauer, J. \& Moncada, J. (1998). Pesticide residue assessment in three selected agricultural production systems in the Choluteca River Basin of Honduras. Environmental Pollution, Vol. 103, No. 2, 171-181, ISSN 0269-7491.

Kirksey, K.B.; Hayes, R. M.; Krueger, W.A. \& Mueller, T.C. (1996). Clomazone dissipation in two Tennessee soils. Weed Science, Vol. 44, No. 4, 959-963, ISSN 1550-2759.

Kolpin, D.W.; Thurman, E.M. \& Linhart, S.M. (1998). The environmental occurrence of herbicides: The Importance of degradates in ground water. Archives of Environmental Contamination and Toxicology, Vol. 35, No. 3, 385-390. ISSN 1432-0703.

Kolpin, D.W.; Thurman, E.M. \& Linhart, S.M. (2000). Finding minimal herbicide concentration in ground water? Try looking for their degradates. Science of the Total Environment, Vol. 248, No. 2-3, 115-122, ISSN 0048-9697.

Konstantinou, I.; Hela, D. \& Albanis, T. (2006). The status of pesticide pollution in surface waters (rivers and lakes) of Greece. Part I. Review on occurrence and levels, Environmental Pollution, Vol. 141, No. 3, 555-570, ISSN 0269-7491.

Kraemer, A.F.; Marchesan, E.; Avila, L.A.; Machado, S.L.O.; Grohs, M.; Massoni, P.F.S. \& Sartori, G.M.S. (2009). Persistence of the herbicides imazethapyr and imazapic in irrigated rice soil. Planta Daninha, Vol. 27, No. 3, 581-588, ISSN 0100-8358.

Kurz, M.H.S. (2007). Study of methods using solid-ohase extraction and analysis by HPLCDAD and GC-ECD for the determination of pesticide residues in waters and field degradation. Doctoral thesis, Universidade Federal de Santa Maria, Brazil.

Kurz, M.H.S.; Gonçalves, F.F.; Martel, S.; Adaime, M.B.; Zanella, R.; Machado, S.L. de O. \& Primel, E.G.. (2009). Rapid and accurate hplc-dad method for the determination of the herbicide bispyribac-sodium in surface water, and its validation. Química Nova, Vol. 32, No. 6, 1457-1460, ISSN 0100-4042.

Kuster, M.; Alda, M. L. \& Barceló, D. (2006) Analysis of pesticides in water by liquid chromatography-tandem mass spectrometric techniques. Mass Spectrometry Reviews, Vol. 25, No. 6, 900-916, ISSN 1098-2787.

Laganà, A.; Bacaloni, A.; Leva, I.; Faberi, A.; Fago, G. \& Marino, A. (2002). Occurrence and determination of herbicides and major transformation products in environmental waters, Analytica Chimica Acta, Vol. 462, No. 2, 187-198, ISSN 0003-2670. 
Lavy, T.L.; Mattice, J.D. \& Norman, R.J. (1998). Environmental implications of pesticides in rice production. In: Rice research studies. Norman, R.J. \& Johnston, T.H. (Ed.), 63-71, Arkansas Agricultural Experimental Station. Fayetteville-Arkansas.

Lee, D.J.; Senseman, S.A.; O’barr, J.H.; Chandler, J.M.; Krutz, L.J. \& Mccauley, G.N. (2004). Soil characteristics and water potential effects on plant-available clomazone in rice. Weed Science, Vol. 52, 310-318, ISSN 1550-2759.

Loux, M.M. \& Reese, K.D. (1992). Effect of soil pH on adsorption and persistence of imazaquin. Weed Science, Vol. 40, No. 3, 490-496, ISSN 1550-2759.

Machado, S. L. de O. (2003). Sistemas de implantação de lavouras de arroz irrigado, consumo de água, perdas de nutrientes na água de drenagem, persistência de herbicidas na água e efeitos em jundiá. Doctoral thesis, Universidade Federal de Santa Maria, Brazil.

Machado, S.L. de O.; Marchezan, E.; Righes, A.A.; Carlesso, R.; Villa, S.C.C. \& Camargo, E.R. (2006). Water use and nutrients and sediments losses on the initial water drainage on flooded rice. Ciência Rural, Vol. 36, No. 1, ISSN 0103-8478.

Mallipudi, N.M.; Stout, S.J.; DaCunha, A.R. \& Lee, A.H. (1991). Photolysis of imazapyr (AC 243997) herbicide in aqueous media. Journal of Agricultural and Food Chemistry, Vol. 39, No. 2, 412-417, ISSN 1520-5118.

Marchesan, E.; Meneghetti, G.; Sartori, S.; Avila, L.; Machado, S.; Zanella, R.; Primel, E.; Macedo, V. \& Marchezan, M. (2010). Resíduos de agrotóxicos na água de rios da Depressão Central do Estado do Rio Grande do Sul, Brasil, Ciência Rural, Vol. 40, No. 5, 1053-1059, ISSN 0103-8478.

Marchesan, E.; Zanella, R.; Avila, L.; Camargo, E.; Machado, S. \& Macedo, V. (2007). Rice herbicide monitoring in two brazilian rivers during the rice growing season, Scientia Agricola, Vol. 64, No. 2, 131-137, ISSN 0103-9016.

Marcolin, E.; Macedo, V.R.M. \& Genro Junior, S.A. (2003). Persistência do herbicida imazethapyr na lâmina de água em três sistemas de cultivo de arroz irrigado, Proceedings of the Brazilian Rice Meeting, pp. 686-688. Camboriú, Epagri, Camboriú, SC, Brazil.

Martini L.F.D.; Avila, L.A.; Souto, K.M.; Cassol, G.V., Refatti, J.P.; Marchesan, E. \& Barros, C.A.P. (2011). Imazethapyr + imazapic leaching in lowland soil as affected by rice irrigation management. Planta Daninha, Vol. 29, No.1, 185-193, ISSN 0100-8358.

McPherson, A. K.; Moreland, R. S.; Atkins, J. B. (2003). Occurrence and Distribution of Nutrients, Suspended Sediment, and Pesticides in the Mobile River Basin, Alabama, Georgia, Mississippi, and Tennessee, 1999-2001. Water-Resources Investigations Report 03-4203, U.S. Geological Survey: Montgomery, pp 1-2, 44, 57.

Mervosh, T.L.; Simms, G.K.; Stoller, E.W. (1995). Clomazone fate as affected by microbial activity, temperature, and soil moisture. Journal of Agricultural and Food Chemistry, Vol. 43, No. 2, 537-543, ISSN 1520-5118.

Miron, D.S.; Crestani, M.; Shettinger, R. M; Morsch, V. M.; Baldisserotto, B.; Tierno, M. A.; Moraes, G.; Vieira, V. L. (2005). Effects of the herbicides clomazone, quinclorac, and metsulfuron methyl on acetylcholinesterase activity in the silver catfish (Rhamdia quelen) (Heptapteridae). Ecotoxicology and Environmental Safety, Vol. 61, No. 3, 398403, ISSN: 0147-6513.

Moraes, B.S.; Clasen, B.; Loro, V.L.; Pretto, A.; Toni, C.; Avila, L.A.; Marchesan, E.; Machado, S.L.O.; Zanella, R. \& Reimche, G.B. (2011). Toxicological responses of Cyprinus carpio after exposure to a herbicide containing imazethapyr and imazapic. Ecotoxicology and Environmental Safety. Vol. 74, No. 3, 328-335, ISSN: 0147-6513. 
Nakano, Y.; Miyazaki, A.; Yoshida, T.; Ono, K. \& Inoue, T. (2004). A study on pesticide runoff from paddy fields to a river in rural region - 1: field survey of pesticide runoff in the Kozakura River, Japan. Water Research, Vol. 38, No. 13, 3017-3022, ISSN 0043-1354.

Noldin, J.A.; Ederhardt, D.S.; Deschamps, F.C. \& Hermes, L.C. (2001). Strategies for water sampling for monitoring the rice enviromental impact. Proceedings of the Brazilian Rice Meeting, pp.760-762, Porto Alegre, 2001, IRGA, Porto Alegre, Brazil.

Noldin, J.A.; Hermes, L.C.; Rossi, M.A. (1997). Persistence of clomazone in pre-germinated rice paddy water. Proceedings of the Brazilian Rice Meeting, pp.363-364, Camboriú, SC, Brazil.

Numabe A. \& Nagahora, S. (2006). Estimation of pesticide runoff from paddy fields to rural rivers. Water Science and Technology, Vol. 53, No. 2, 139-146, ISSN 0273-1223.

Palma, G.; Sánchez, A.; Olave, Y.; Encina, F.; Palma, R. \& Barra, R. (2004). Pesticide levels in surface waters in an agricultural-forestry basin in Southern Chile, Chemosphere, Vol. 57, No. 8, 763-770. ISSN 0045-6535.

Pastorelli, R.; Catenacci, G.; Guanci, M.; Fanelli, R.; Valoti, E.; Minoia, C. \& Airoldi, L. (1998). 3,4-Dichloroaniline-haemoglobin adducts: Preliminary data on agricultural workers exposed to propanil. Biomarkers, Vol. 3, No. 3, 227-233, ISSN 1366-5804.

Peixoto, S.C. (2007). Study of field pesticide stability of carbofuran and quinclorac in the water of irrigated rice crops using SPE and HPLC-DAD. Master dissertation, Universidade Federal de Santa Maria, Brazil.

Pereira, W.E. \& Hostettler, F.D. (1992). Nonpoint source contamination of the Mississippi River and its tributaries by herbicides. Environmental Science and Technology, Vol. 27, No. 8, 1542-1552, ISSN 1520-5851.

Pereira, W.E. \& Rostad, C.E. (1990). Occurrence, distributions, and transport of herbicides and their degradation products in the lower Mississippi River and its tributaries. Environmental Science and Technology, Vol. 24, No. 9, 1400-1406, ISSN 1520-5851.

Pretto, A.; Loro, V.L.; Menezes, C.; Moraes, B.S.; Reimche, G.B.; Zanella, R.; de Avila, L.A. (2011). Commercial formulation containing quinclorac and metsulfuron-methyl herbicides inhibit acetylcholinesterase and induce biochemical alterations in tissues of Leporinus obtusidens. Ecotoxicology and Environmental Safety, Vol. 74, No. 3, 336341, ISSN: 0147-6513.

Primel, E.G. (2003). Application of solid-phase extraction and chromatographic techniques for the determination of herbicides in surface water and accompaniment of the degradation in field and in laboratory. Doctoral thesis, Universidade Federal de Santa Maria, Brazil.

Primel, E.G.; Zanella, R.; Kurz, M.H.S.; Gonçalves, F.F.; Machado, S.L.O. \& Marchezan, E. (2005). Pollution of water by herbicides used in the irrigated rice cultivation in the central area of Rio Grande do Sul state, Brazil: theoretical prediction and monitoring. Química Nova, Vol. 28, No. 4, 605-609, ISSN 0100-4042.

Quayle, W.C. (2003). Persistence of rice pesticides in floodwaters: influence of water management. Proceedings of the 3rd International Temperate Rice Conference, pp. 97, Vol. 3, Punta del Este, Uruguay, INIA.

Reimche, G.B. (2010). Impacto de agroquímicos usados na lavoura de arroz irrigado sobre a qualidade da água de irrigação e na sobre a comunidade zooplanctônica. Master dissertation, Universidade Federal de Santa Maria, Brazil.

Reimche, G.B.; Machado, S.L.O.; Golombieski, J.I.; Baumart, J.S.; Braun, N.; Marchesan, E. \& Zanella, R. (2008). Water persistence and influence of herbicides utilized in rice 
paddy about zooplankton community of Cladocers Copepods and Rotifers. Ciência Rural, Vol. 38, No.1, 7-13, ISSN 0103-8478.

Resgalla, C.Jr; Noldin, J.A.; Tamanaha, M.S.; Deschamps, F.C.; Eberhardt, D.S. \& Rörig L.R. (2007). Risk analysis of herbicide quinclorac residues in irrigated rice areas, Santa Catarina, Brazil. Ecotoxicology, Vol. 16, No. 8, 565-571, ISSN 1573-3017.

Ross, L.J.; Powell, S. and Fleck, S.L. (1989). Dissipation of bentazon in flooded rice field. Journal of Environmental Quality, Vol. 18, No. 1, 105-109, ISSN 1537-2537.

Sanches-Brunete, C.; Perez, S. \& Tadeo, J.L. (1991). Determination of phenoxy ester herbicides by gas and high-performance liquid chromatography. Journal of Chromatography A, Vol. 552, No. 1-2, 235-240, ISSN 0021-9673.

Santos, F.M.; Marchesan, E.; Machado, S.L.O.; Avila, L.A.; Zanella, R. \& Gonçalves, F.F. (2008). Imazethapyr and clomazone persistence in rice paddy water. Planta Daninha, Vol. 26, No. 4, 875-881, ISSN 0100-8358

Santos, T.C.R., Rocha, J.C., Barceló, D. (2000). Determination of rice herbicides, their transformation products and clofibric acid using on-line solid-phase extraction followed by liquid chromatography with diode array and atmospheric pressure chemical ionization mass spectrometric detection. Journal of Chromatography A, Vol. 879, No. 1, 3-12, ISSN 0021-9673.

Santos, T.C.R.; Rocha, J.C.; Alonso, R.M.; Martinez, E.; Ibanez, C. \& Barceló, D. (1998). Rapid degradation of propanil in rice crop fields. Environmental Science and Technology, Vol. 32, No. 22, 3479-3484, ISSN 1520-5851.

Senseman, S.A. (Ed.) (2007). Herbicide handbook. 9th ed., Lawrence: Weed Science Society of America. ISBN: 978-1891276569, Lawrence, KS. 458 pp.

Siemering, G.S., Hayworth, J.D. \& Greenfield, B.K. (2008). Assessment of potential aquatic herbicide impacts to California aquatic ecosystems. Archives of Environmental Contamination and Toxicology, Vol. 55, No. 3, 415-31, ISSN 1432-0703.

Silva, D.; Avila, L.; Agostinetto, D.; Dal Magro, T.; Oliveira, E.; Zanella, R. \& Noldin, J. (2009). Monitoramento de agrotóxicos em águas superficiais de regiões orizícolas no sul do Brasil, Ciência Rural, Vol. 39, No. 9, 2383-2389, ISSN 0103-8478.

Solomon, K.R.; Baker, P.R.; Dixon, K.R.; Klaine, S.J.; LaPoint, T.W.; Kendall, R.J.; Weisskopf, C.P.; Giddings, J.M.; Giesy, J.P.; Hall, L.W. \& Williams, W.M. (1996). Ecological risk assessment of atrazine in North American surface waters. Environmental Toxicology and Chemistry, Vol. 15, No. 1, 31-76, ISSN 1552-8618.

Son, H.V.; Ishihara, S. \& Watanabe, H. (2006). Exposure risk assessment and evaluation of the best management practice for controlling pesticide runoff from paddy fields. Part 1: Paddy watershed monitoring. Pest Management Science, Vol. 62, No. 12, 11931206, ISSN: 1526-4998.

Squillace, P.J. \& Thurmann, E.M. (1992). Herbicide transport in rivers: Importance of hydrology and geochemistry in nonpoint-source contamination. Environmental Toxicology and Chemistry, Vol. 26, No. 3, 538-545, ISSN 1552-8618.

Steckert, A.V.; Schnack, C.E.; Silvano, J.; Dal-Pizzol, F. \& Andrade, V.M. (2009). Markers of pesticide exposure in irrigated rice cultures. Journal of Agricultural and Food Chemistry, Vol. 57, No. 23, 11441-11445, ISSN 1520-5118.

Stougaard, R.N.; Shea, P.J. \& Martin, A.R. (1990). Effect of soil type and pH on adsorption, mobility and efficacy of imazaquin and imazethapyr. Weed Science, Vol. 36, No. 1, 67-73, ISSN 1550-2759.

Sudo, M.; Kunimatsu, T. \& Okubo, T. (2002). Concentration and loading pesticides residues in Lake Biwa Basin (Japan). Water Research, Vol. 36, No. 1, 315-329, ISSN 0043-1354. 
Tarazona, J.V. \& Sanchez, P. (2006). Development of an innovative conceptual model and a tiered testing strategy for the ecological risk assessment of rice pesticides. Paddy and Water Environment, Vol. 4, No. 1, 53-59, ISSN 1611-2504.

Thurman, E.M.; Goolsby, D.A.; Meyer, M. T. \& Kolpin, D.W. (1991). Herbicides in surface waters of the Midwestern United States: The effect of spring flush. Environmental Science and Technology, Vol. 25, No. 10, 1794-1796, ISSN 1520-5851.

Thurman, E.M.; Goolsby, D.A.; Meyer, M. T.; Mills, M.S.; Pomes, M.I. \& Kolpin, D.W. (1992). A reconnaissance study of herbicides and their metabolites in surface water of the Midwestern United States using immunoassay and gas chromatography/mass spectrometry. Environmental Science and Technology, Vol. 26, No. 12, 2440-2447, ISSN 1520-5851.

Tomlin, C.D.S. (2007). A world compendium: the e-Pesticide Manual, 14th ed. CDROM version 4.0, The British Crop Protection Councill, Farnham, UK. ISBN 1-901396-42-8

Ueji, M. \& Inao, K. (2001). Rice paddy field herbicides and their effects on the environment and ecosystems. Weed Biology and Management, Vol. 1, No. 1, 71-79, ISSN 1445-6664.

U.S. Department of Agriculture - USDA (2007). Pesticide Data Program Annual Summary, Calendar Year 2006, Agricultural Marketing Service: Washington, DC.

Vencill, W. K. (2002). Herbicide Handbook, 8th ed., Weed Science Society of America, ISBN 1891276336, Lawrence, KS.

Walls, D.; Smith, P.G. \& Mansell, M.G. (1996). Pesticides in groundwater in Britain. International Journal of Environmental Health Research, Vol. 6, No. 1, 55-62, ISSN 13691619.

Ware, G. W. (1994). The Pesticide Book, 4th ed., Thomson Publications, ISBN: 0913702587, Fresno, CA.

Woudneh, M.B.; Ou, Z.; Sekela, M.; Tuominen, T. \& Gledhill, M. (2009). Pesticide multiresidues in waters of the Lower Fraser Valley, Canada. Part I. Surface water. Journal of Environmental Quality, Vol. 8, No. 3, 940-947, ISSN: 00472425.

Zanella, R.; Primel, E.G.; Gonçalves, F.F.; Kurz, M.H.S. \& Mistura, C.M. (2003) Development and validation of a high-performance liquid chromatographic procedure for the determination of herbicide residues in surface and agriculture waters. Journal of Separation Science, Vol. 26, No. 9-10, 935-938, ISSN 1615-9314.

Zanella, R.; Primel, E.G.; Machado, S.L.O.; Gonçalves, F.F. \& Marchezan, E. (2002). Monitoring of the Herbicide Clomazone in Environmental Water Samples by SolidPhase Extraction and High-Performance Liquid Chromatography with Ultraviolet Detection, Chromatographia, Vol. 55, No. 9-10, 573-577, ISSN 1612-1112.

Zanella, R.; Primel, E.G.; Gonçalves, F.F. \& Martins, A.F. (2000). Development and validation of a high-performance liquid chromatographic method for the determination of clomazone residues in surface water. Journal of Chromatography A, Vol. 904, No. 2, 257-262, ISSN 0021-9673. 


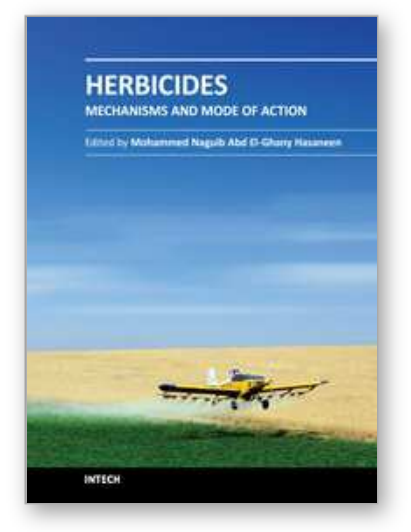

\author{
Herbicides - Mechanisms and Mode of Action \\ Edited by Dr. Mohammed Nagib Hasaneen
}

ISBN 978-953-307-744-4

Hard cover, 204 pages

Publisher InTech

Published online 22, December, 2011

Published in print edition December, 2011

This volume contains two sections: Mechanisms of herbicidal action (chapters 1-4) and Mode of action of selected herbicides on controlling diseased, weed growth and productivity and/or growth and development of field crops (chapters 5-10). Topics by chapters are: molecular mechanism of action, immunosensors , laboratory studies, molecular modeling, weed resistance, community response, use of herbicides in biotech culture, gene flow, herbicides and risk, herbicides persistence. These recurring themes reinforce my view, held over a very long time, that experience with one crop or problem can sometimes be relevant, often to an unexpected extent, to an apparently dissimilar situation in a different crop. I hope that readers interested in herbicides and pesticides will be satisfied with all the chapters in the book as its content might be of interest and value to them in the future.

\title{
How to reference
}

In order to correctly reference this scholarly work, feel free to copy and paste the following:

Renato Zanella, Martha B. Adaime, Sandra C. Peixoto, Caroline do A. Friggi, Osmar D. Prestes, Sérgio L.O. Machado, Enio Marchesan, Luis A. Avila and Ednei G. Primel (2011). Herbicides Persistence in Rice Paddy Water in Southern Brazil, Herbicides - Mechanisms and Mode of Action, Dr. Mohammed Nagib Hasaneen (Ed.), ISBN: 978-953-307-744-4, InTech, Available from: http://www.intechopen.com/books/herbicidesmechanisms-and-mode-of-action/herbicides-persistence-in-rice-paddy-water-in-southern-brazil

\section{INTECH}

open science | open minds

\author{
InTech Europe \\ University Campus STeP Ri \\ Slavka Krautzeka 83/A \\ 51000 Rijeka, Croatia \\ Phone: +385 (51) 770447 \\ Fax: +385 (51) 686166 \\ www.intechopen.com
}

\author{
InTech China \\ Unit 405, Office Block, Hotel Equatorial Shanghai \\ No.65, Yan An Road (West), Shanghai, 200040, China \\ 中国上海市延安西路65号上海国际贵都大饭店办公楼 405 单元 \\ Phone: +86-21-62489820 \\ Fax: +86-21-62489821
}


(C) 2011 The Author(s). Licensee IntechOpen. This is an open access article distributed under the terms of the Creative Commons Attribution 3.0 License, which permits unrestricted use, distribution, and reproduction in any medium, provided the original work is properly cited. 